Bayero Journal of Pure and Applied Sciences, 10(1): 234 - 238

ISSN 2006 - 6996

\title{
METAL CONTENT DETERMINATION OF SOME SEXUAL DYSFUNCTION MEDICINE SAMPLES IN NORTHERN NIGERIA
}

\author{
${ }^{*}$ Samali, ${ }^{1}$ A., Mohammed, ${ }^{1}$ M. I., Ibrahim, ${ }^{1}$ M. B. and Gamaniel ${ }^{2}$, K.S. \\ ${ }^{1}$ Department of Pure and Industrial, Faculty of Science, Bayero University Kano, Kano State, \\ Nigeria. \\ ${ }^{2}$ Director-General Office, National Institute for Pharmaceutical Research and Development (NIPRD) \\ Idu Industrial Area, Federal Ministry of Health Abuja, Nigeria.
}

Corresponding author: ayubasamali@yahoo.com; mbibrahim.chm@buk.edu.ng; 08069822624

\begin{abstract}
Essential minerals are those that are necessary for normal physiological and biological functions of human body. They act as catalysts such that only trace amount are necessary for cellular function. The study analyzed nine (9) different sex-drive herbal preparations used in the North-western part of Nigeria for essential minerals using Atomic Absorption Spectrophotometric (AAS) method in order to ascertain relationship between sex-drive and the mineral content of these herbal medicines. The result obtained shows the range of the mean concentration of $\mathrm{Fe}, \mathrm{Cu}, \mathrm{Mn}$, and $\mathrm{Zn}$ to be $(231.13-440.64) \mu \mathrm{g} / \mathrm{g},(7.74-25.93) \mu \mathrm{g} / \mathrm{g}$, $(14.09$ - 59.66) $\mu \mathrm{g} / \mathrm{g}$ and $(6.86-74.41) \mu \mathrm{g} / \mathrm{g}$ respectively. The presence of $\mathrm{Fe}, \mathrm{Cu}$ and $\mathrm{Zn}$ indicated the potential role of these herbal preparations in alleviation of sexual dysfunction problems and serves as sex-drivers. The average concentration of $\mathrm{Cu}$ and $\mathrm{Zn}$ obtained in the samples were above the World Health Organization (WHO) and US Food and Drugs Administration (FDA) permissible limit in herbal drugs as Cu (20ppm) and $\mathrm{Zn}$ (50ppm). The consumers' of these products need to be cautioned otherwise the tendency of overload which will further result to health hazard is certain.
\end{abstract}

Keywords: Herbal medicine, Sex-drive, Essential minerals

\section{INTRODUCTION}

Herbal medicines have been used for solving wide range of health challenges including sexual-dysfunction and other related problems such as sexually transmitted diseases, erectile dysfunctions, and fertility problems, cervical and prostate cancers. Some of these medicines are considered more effective, where modern medicine has either failed to produce equally good results or has simply ignored the need for systematic attention and research (Verma and Singh, 2008; Okigbo and Mmeka, 2006; Twumasi, 2005; WHO, 2003; Yeboah, 2000).

Sex-drive is a biological need or craving that inspires individuals to seek out and become receptive to sexual experiences and sexual pleasure according to Baumeister et al. (2001). Chronic illness/disorder such as cardiovascular disease, diabetes, arthritis, high-blood pressure, enlarge prostates (in men), Parkinson's disease and cancer can have serious effect on biological drive and psychological motivation for sexual desire, functioning and response of an individual (Levine, 2003; Regan and Atkins, 2006). According to DeLamater and Sill, (2005), the use of anticoagulants, cardiovascular medications, medications to control cholesterol, and medications for hypertension by women contributed to low levels of desire, while in men, only the use of anticoagulants and medications for hypertension was related to low levels of desire (DeLamater and Sill, 2005).

Literature have documented the use of plants in the traditional medicine systems of many cultures (Chang and But, 2001) and Northwestern part of Nigeria inclusive. Some of these plants are used for the preparation of herbal medicines for the treatment of several disease conditions including sexual dysfunction. Several studies have also been conducted on essential minerals content of herbal medicines. However, limited and scanty information are available with respect to their relationship with certain disease condition most especially in Nigerian herbal medicine system despite high level of reliance on them as source of treatment (Chizola and Franz, 1996). This fact therefore, necessitate the need for this study which analyzed some essential minerals (copper, iron, manganese and zinc) content of sex-drive herbal preparations commonly sold in the markets of the North-western states of Nigeria in order to ascertain their presence and possibly relate them to sexual dysfunction/sexdrive conditions. Literatures have reported several techniques such as atomic absorption spectrometry (AAS); atomic emission/ fluorescence spectrometry (AES/AFS); inductively coupled plasma optical emission spectrometry (ICP-OES); inductively coupled plasma mass spectrometry (ICP-MS); X-ray fluorescence (XRF); anodic striping 
voltammeter (AVS) and neutron activation analysis (NAA) that have been used for the determination of essential metals (Helaluddin et al., 2016). In this study Atomic Absorption Spectrometer (AAS) was selected to be used due to its availability, accessibility, simplicity of application, sensitivity and easy understanding principles (Skoog et al, 2007).

\section{MATERIALS AND METHODS \\ Sampling}

The major popular Kurmi market in Kano State, Central market in Kaduna State, Central mosque market square in Katsina State, Central market in Kebbi State, Hadeja/Gujungu markets in Jigawa State, Gusau New market in Zamfara State were chosen as sampling sites and visited on market days for sample collection. Oral enquiry was conducted at the point of purchase where the sellers provided information on the samples and documented accordingly in the month of June 2015 (Mohammed et al, 2016).

Sample digestion Procedure

The digestion procedure used for sample preparation was adopted from Sneddon et al. (2006) and validated by Mohammed et al. (2016). Finely powdered samples $(1.0 \mathrm{~g})$ each were weighed into beakers and concentrated nitric acid $\left(20 \mathrm{~cm}^{3}\right)$ was added and kept for 24 hours. The samples were carefully heated on a powered electrically connected sand-bath in fume hood chamber with periodic addition of concentrated nitric acid $\left(10 \mathrm{~cm}^{3}\right)$ until the production of red nitrous oxide $\left(\mathrm{NO}_{2}\right)$ ceased. The samples were cooled and perchloric acid $\left(\mathrm{HClO}_{4}\right)\left(4 \mathrm{~cm}^{3}\right)$ was further added and heated until the clear sample solution was obtained. The samples were diluted with deionized water, filtered into volumetric flasks $\left(100 \mathrm{~cm}^{3}\right)$ and then made up to the mark. This was transferred into a capped labeled plastic bottle and kept in fridge prior to analysis. A Blank sample solution was also prepared under the same experimental conditions used for the sample preparation, only that no sample analyte was involved in the process.

\section{Preparation of Standard Solutions}

$1000 p p m$ standards solutions of the metals of interest ( $\mathrm{Cu}, \mathrm{Fe}, \mathrm{Mn}$ and $\mathrm{Zn}$ ) were prepared by weighing out accurately $1.0 \mathrm{~g}$ of the pure metal, dissolved in concentrated nitric acid $\left(10 \mathrm{~cm}^{3}\right)$ and made up to the mark in $1 \mathrm{dm}^{3}$ volumetric flask using deionized water (Dhanlal, 2000). Appropriate concentrations of working standards of the $\mathrm{Cu}, \mathrm{Fe}, \mathrm{Mn}$ and $\mathrm{Zn}$ were prepared from the stock solutions by dilution appropriate volumes in $100 \mathrm{~cm}^{3}$ volumetric flask with deionized water and transferred into capped plastic bottle prior to absorbance measurement using Atomic Absorption Spectrometer (SpectrAA 240 Model).

Analytical Procedure

The concentrations of $\mathrm{Cu}, \mathrm{Fe}, \mathrm{Mn}$ and $\mathrm{Zn}$ in the sex-drive herbal medicine samples were analyzed using SpectrAA 240 Model of Fast Sequential Atomic Absorption Spectrometer. The equipment was optimized and calibrated based on the operating conditions specified in Table 1. The data obtained were processed by calculating the actual concentrations in the samples analyzed using the relation in equation 1.

$$
\text { Metal }\left(\mu \frac{g}{g}\right)=\frac{C \times v \times d f}{W}
$$

where $C$ is the concentration of the sample analyte in $\mu \mathrm{g} / \mathrm{mL} ; \quad V$ is the volume of the sample solutions in $\mathrm{cm}^{3}$; $W$ is the sample's weight in grams and d.f is the dilution factor (Mohammed et al., 2016; Chionyedua et al., 2015; AAS Manual, 1996).

Table 1:- Instrumental Operating Conditions

\begin{tabular}{lllllll}
\hline Element & wavelength & $\begin{array}{l}\text { Detection limit } \\
(\mu \mathrm{g} / \mathrm{ml})\end{array}$ & $\begin{array}{l}\text { Slit width } \\
(\mathrm{nm})\end{array}$ & $\begin{array}{l}\text { Lamp } \\
\text { Current } \\
(\mathrm{mA})\end{array}$ & $\begin{array}{l}\text { Nebulizer } \\
\text { uptake }\end{array}$ & $\begin{array}{l}\text { Gas flow } \\
\text { (Air/acetylene) }\end{array}$ \\
\hline $\mathrm{Cu}$ & 324.7 & 0.02 & 0.5 & 3.0 & $5 \mathrm{ml} / \mathrm{min}$ & $13.5 / 2.0$ \\
$\mathrm{Fe}$ & 372.0 & 0.45 & 0.2 & 7.0 & $5 \mathrm{ml} / \mathrm{min}$ & $13.5 / 2.0$ \\
$\mathrm{Mn}$ & 279.5 & 0.03 & 0.2 & 5.0 & $5 \mathrm{ml} / \mathrm{min}$ & $13.5 / 2.0$ \\
$\mathrm{Zn}$ & 213.9 & 0.008 & 0.5 & 5.0 & $5 \mathrm{ml} / \mathrm{min}$ & $13.5 / 2.0$ \\
\hline
\end{tabular}

Equipment Suitability Test

In this study, suitability of the equipment was conducted and the method used was quality reference standards from which calibration curves of acceptable weighted-linear correlation coefficients $(\geq 0.995)$ were generated and optimization of the equipment prior to sample analysis.
Statistical Data Analysis

All the data obtained were subjected to statistical analysis using Microsoft Excel 2010 and the final results reported as Mean, range and standard deviation (Kophkar, 2008). 


\section{RESULTS AND DISCUSSION}

Essential minerals are among the important micronutrients used in health care system due to realization of their importance in disease management, treatment and cure. The properties and activities of essential minerals in chemical reactions are the main reasons of their therapeutic activities (Elizabieta et al., 2014), this therefore explained why their use has gained interest and popularity over the years globally in handling a wide range of diseases conditions. The relationships existing between the essential minerals ( $\mathrm{Cu}, \mathrm{Fe}, \mathrm{Mn}$ and $\mathrm{Zn}$ ) content of the herbal medicines analyzed and sexual dysfunction condition are explained with reference to previous literature (Moses et al., 2012).

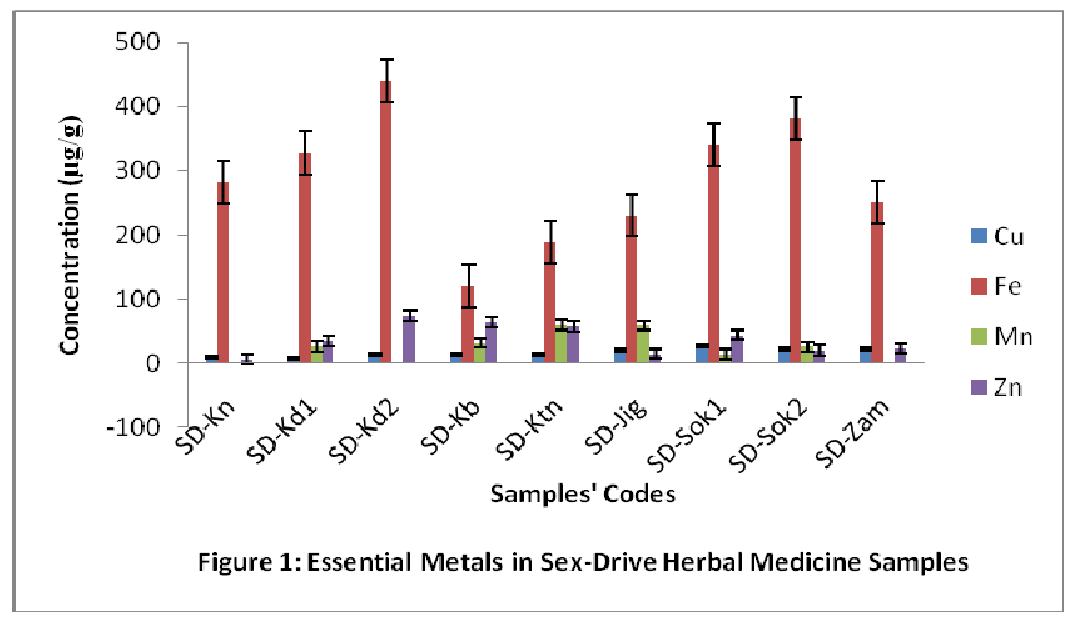

Figure 1 presents concentrations of the essential metals; Fe, $\mathrm{Zn}, \mathrm{Mn}$ and $\mathrm{Cu}$ determined in sex-drive herbal medicines samples which were obtained from Kano (SD-Kn), Kaduna (SD-Kd1, Kd2), Katsina (SD-Ktn) and Sokoto (SD1-Sok1, Sok2) states. The results shows the highest concentrations of Fe, $\mathrm{Zn}, \mathrm{Mn}$ and $\mathrm{Cu}$ in Kaduna (SD-Kd2), Kaduna (SD-Kd2), Katsina (SD-Ktn) and Sokoto (SD- Sok1) as $440.64 \pm 0.58,74.41 \pm 0.20,59.66 \pm 0.11$ and $25.93 \pm 0.88 \mu \mathrm{g} / \mathrm{g}$ respectively which are depicted graphically.

The Required Daily Allowance (RDA) values of $\mathrm{Cu}, \mathrm{Fe}, \mathrm{Mn}$ and $\mathrm{Zn}$ for adults were $900 \mathrm{mg} /$ day, $8-18 \mathrm{mg} /$ day, $2.3-18 \mathrm{mg} /$ day and $8-11 \mathrm{mg} /$ day respectively (DRI, 2001) which indicated the highest concentration of $\mathrm{Fe}, \mathrm{Zn}$ and $\mathrm{Mn}$ obtained in the sex-drive herbal medicines analyzed to be above the RDA value with only $\mathrm{Cu}$ below. Iron $(\mathrm{Fe})$ is a necessary requirement for blood volume increase for all sex at all age groups (DRIs, 2001) for various functions among which is optimal sex performance. Zinc (Zn) increases semen volume and testosterone level for male sexual vitality, 30-60 mg per day has been recommended for male fertility while its deficiency result to infertility, impotency, or poor reproductive system development(Rungby, 2010). Copper ( $\mathrm{Cu}$ ) plays a similar role with $\mathrm{Zn}$, therefore its presence also contributes to enhance sexual activities. The presence of these essential metals are the contributing factors for the potentiality of these sex-drive herbal medicines, however, their consumption by the users' have to be moderate otherwise it could lead to $\mathrm{Fe}, \mathrm{Zn}$ and $\mathrm{Mn}$ overload or imbalance in the body system and results to health challenges. For example, zinc (Sun et al. 2008) could affect pancreatic islet and cause development of diabetes due to production of reactive oxygen species (Khan and Awan, 2014) which could further decrease the insulin gene promoter activity and mRNA expression in pancreatic islet cells due to hyperglycemic condition according to the reports of Guidotti et al. (2010), Valko et al. (2005) and Galhardi et al. (2004).

The traditional herbal medicine practitioners from the study area have a belief that pile (hemorrhoids or hemorrhoidal) disease condition is associated to consumption of oily and sugary food substances and is one of the factors contributing to sexual dysfunction. As a result some of them emphasized that the sexdrive herbal preparations they administer has potential to flush-out both oily and sugary substances from the body system which in-turn restore vitality and sex-drive of an individual suffering from sexual dysfunction condition. Piles (hemorrhoids or hemorrhoidal) disease according to medical terminology is commonly observed in both men and women. 
Its development is due to the excessive swelling or inflammation of blood vessels in and around the anal canal according to Schubert et al. (2009). Reese et al. (2009) reported that, the exact cause of symptomatic hemorrhoids is unknown, but number of factors which are suspected to play a role includes, lack of exercise, low-fiber diets, prolong straining, intra-abnormal mass, genetics, prolong sitting, obesity, lack of valves within the hemorrhoidal veins and aging (Lorenzo-Rivero, 2009; KaidarPerson et al., 2007).

\section{CONCLUSION}

The result of the study was able to establish that, sex-drive herbal preparations are popularly known and used in the North-western part of Nigeria. They are rich in Copper (Cu), Iron (Fe), Zinc (Zn) and Manganese (Mn). Their specific roles relates to sexual vitality includes

\section{REFERENCES}

AAS Manual, (1996).Analytical Methods for Atomic Absorption Spectroscopy, Perkin Elmer Inc. Printed in United States of America Manual no.0303-0152 (D). p. 46-47

Baumeister, R. F., Catanese, K. R. and Vohs, K. D.(2001)."Is There a Gender Difference in Strength of Sex Drive? Theoretical Views, Conceptual Distinctions, and a Review of Relevant Evidence". Personality and Social Psychology Review. 5 (3): 242

Chang, H. M. and But, P. P. H. (2001).Pharmacology and Applications of Chinese Materia Medica,Vols. I and II, S.- C.Yao, L.-L. Wang, S. C.-S. Yeung (Translators), World Scientific, Philadelphia. pp.62-87

Chionyedua, T.O., Ngozi, A. and Isiaka, A.O (2015) Levels of Potentially Toxic Minerals In Selected Herbal Medicines In Lagos, Nigeria, Journal of Natural Sciences Research;5 (2): 2015

Chizzola, R. and Franz, C.(1996). Metallic trace elements in medicinal and aromatic plants from Austria, Journal of applied biology; 70, 52-56

DeLamater, J.D. and Sill, M.(2005)."Sexual Desire in Later Life". The Journal of Sex Research. 42 (2): 138-149.

Dhanlal, D.L. (2000). Delloyd's Lab Tech chemistry resources: The Lab Tech resources and techniques used in the analytical chemistry laboratory. Pages 1-6

http://delloyd.50megs.com ${ }^{\circledR}$ Retrived $17^{\text {th }}$ April, 2015 links of copper with enzymes and proteins energy metabolism, iron links with hemoglobin formation and oxygen electron transfer, zinc links with increase semen volume/testosterone, and manganese links with development/metabolism has established a relationship between these metals and sexdrive/desires due to the beliefs that they are capable of alleviating sexual dysfunction conditions and empowers sex-drive of the users. However, the essentiality of these minerals should not be considered as a warrant for indiscriminate and unregulated consumption of these herbal preparations for the sake of satisfying sexual desires, since essential mineral overload can also result to health challenges just as some of these herbal preparations could contain high level of nonessential metals such as lead and cadmium.

Dietary Reference Intakes (DRIs, 2001). Recommended Dietary Allowances and Adequate Intakes, Elements "Vitamin A, Vitamin K, Arsenic, Boron, Chromium, Copper, lodine, Iron, Manganese, Molybdenum, Nickel, Silicon, Vanadium, and Zinc" Dietary Reference Intakes (DRIs): Recommended Dietary Allowances and Adequate Intakes, Element; Food and Nutrition Board, Institute of Medicine, National Academies. Pages 1-8,

These reports may be accessed via www.nap.edu.

Elizabieta, P.P., Tuomas, W., Pekka, K., Markus, K. and Faik, A. (2014). Trace elements, antioxidant enzymes and free carnitine Levels among epileptic patients treated with valproate monotherapy; In the book, Pharmacology and Nutritional Intervention in the Treatment of Disease. InTech Chapters, 10.5772/57023, 426 pages.

Galhardi, C.M., Diniz, Y.S., Faine, L.A, Rodrigues, H.G., Burneiko, R.C., Ribas, B.O., Novelli, E.L. (2004): Toxicity of copper intake: lipid concentration, oxidative stress and susceptibility to renal dysfunction. Food Chem. Toxicol.; 42(12):2053-2060.

Guidotti, T., McNamara, J. and Moses, M. (2010: The interpretation of trace element analysis in body fluids. Indian J. Med. Res.; 128(4):524 
Helaluddin, A.B.M., Khalid, R.S., Alaama, M. and Abbas, S.A. (2016): Main Analytical Techniques Used for Elemental Analysis in Various Matrices, Tropical Journal of Pharmaceutical Research; 15 (2): 427434

Kaidar-Person, O; Person, B. and Wexner, S.D. (2007): "Hemorrhoidal disease: A comprehensive review" (PDF); Journal of the American College of Surgeons. 204(1): 102-17

Khan, A.R. and Awan, F.R. (2014). Minerals in the pathogenesis of type 2 diabetes, Journal of Diabetes \& Metabolic Disorders, 13:16

Kophkar, S.M .(2008). Reliability of Analytical Data and Statistical Analysis.Basic Concept of Analytical Chemistry. ${ }^{\text {rd }}$ eds. New Age Int'l (P) Ltd, New Delhi. Pp.6-15

Levine, S. B. (2003). "The nature of sexual desire: A clinician's perspective". Archives of Sexual Behavior. 32(3): 279-285.

Lorenzo-Rivero, S. (2009): "Hemorrhoids: diagnosis and current management". Am Surg. 75(8): 635-42

Mohammed M.I, Ibrahim M.B and Ayuba. S (2016): Distribution of Iron in Herbal Preparations of North-Western States of Nigeria, Book of Proceeding of $2^{\text {nd }}$ Annual International Conference NorthWest University, pp.103-109.

Moses, A.G., Maobe, E. G., Leonard, G. and Henry, R.(2012). Concentration of Heavy Minerals in Selected Medicinal Plants Used for the Treatment of Diabetes, Malaria and Pneumonia in Kisii Region, Southwest Kenya, Global Journal of Pharmacology; 6 (3): 245251

Okigbo, R.N. and Mmeka, E.C.(2006). An Appraisal of Phytomedicine in Africa KMITL Science and Technology Journal;6(2):83-94.

Reese, G.E., Von-Roon, A.C. and Tekkis, P.P. (2009)."Haemorrhoids," Clinical evidence. BMJ Clin Evid: Vols. 2009: 0415
Regan, P.C. and Atkins, L.(2006)."Sex Differences and Similarities in Frequency and Intensity of Sexual Desire", Social Behavior \& Personality: An International Journal. 34 (1): 95-101.

Rungby, J. (2010). Zinc, zinc transporters and diabetes. Diabetologia, 53: 1549-51.

Schubert, M.C., Sridhar, S., Schade, R.R. and Wexner, S.D. (2009). "What every gastroenterologist needs to know about common anorectal disorders", World J Gastroenterol. 15 (26): 3201-9).

Skoog, D.A., Holler, F.J. and Crouch, S.R. (2007).Principles of Instrumental Analysis, $6^{\text {th }}$ edition, Published by Brooks Cole United State; pp.25-36

Sneddon, J., Hardaway, C., Bobbadi, K.K. and Reddy, A.K. (2006). Sample Preparation of Solid samples for Metal Determination by Atomic SpectroscopyAn Overview and Selected Recent Applications. Applied Spectroscopy Reviews; 41 (1):1-14

Sun, Q., Dam, R.M.V., Willett, W.C. and Hu, F.B. (2008): Prospective Study of Zinc Intake and Risk of Type II Diabetes in Women. Diabetes Care; 32(4): 629-634

Twumasi, P.A. (2005). Medical Systems in Ghana: A study in Medical Sociology $2^{\text {nd }}$ Edition. Tema: Ghana Publishing Corporation, pp.1-171

Verma, S. and Singh, S.P. (2008).Current and Future Status of Herbal Medicine." Veterinary World"; 1(11):347-350

Valko, M., Morris, H. and Cronin, M.T. (2005): Minerals, toxicity and oxidative stress. Curr.Med. Chem.; 12(10):1161-1208.

World Health Organization (WHO, 2003). "Traditional Medicine". FiftySixth World Health Assembly, Provisional agenda item 14.10.Geneva: World Health Organization Press. http://whqlibdoc.who.int/wha/2003/W HA56_31.pdf on 07 August 2016)

Yeboah, T. (2000).Improving the Provision of Traditional health Knowledge for Rural Communities in Ghana. Health Libraries Review; 17(4): 203-208. 